\title{
STATE-PRIVATE PARTNERSHIP \\ IN THE SYSTEM OF IRRIGATION MANAGEMENT AND SOLVING WATER CONFLICTS IN UKRAINE
}

\author{
Hranovska Lyudmyla ${ }^{1}$ \\ Kyseliova Ryma ${ }^{2}$
}

DOI: https://doi.org/10.30525/978-9934-571-89-3_97

A state-private partnership can be created in the various fields and branches including irrigation and drainage systems management, and it can be realised in the form of concession, joint activity, the creation of organizations and associations of water consumers [1]. One of the effective forms of the state-private partnership in the sphere of water economy can be the transfer of the rights of intro-farm management, objects of engineering infrastructure and drainage to the level of the unions of water consumers ( associations of water consumers). At the same time, management of the main canals, tubes, and water economy objects of inter-regional importance should be conducted by the regional state structures. Therefore, the system of the state-private partnership in the system of water-meliorative activity can be stated as mutual cooperation of the state bodies with private partners [2].

Associations are not a new organizational and judicial form for the countries of the world, there are such unions of land-users and water consumers in many countries, and the unions proved their high efficiency and capability to conduct the efficient water resources and meliorative systems management on practice. However, the experience of many countries, which had already introduced the state-private partnership in the system of water economy by the creation of water consumers association, is actual for Ukraine. The governments of these countries conducted active work on the development of the necessary legislative and normative basis for the creation of water consumers associations, determination of their functions and tasks. However, the hopes of the governments on the effective work of the water consumers associations was not justified everywhere. Every country had typical financial problems - associations did not have enough fundings to maintain and

\footnotetext{
${ }^{1}$ Institute of Irrigated Agriculture

of the National Academy of Agrarian Sciences of Ukraine, Ukraine

${ }^{2}$ Institute of Irrigated Agriculture

of the National Academy of Agrarian Sciences of Ukraine, Ukraine
} 
exploit meliorative systems, hydrotechnological constructions, and pump stations. According to the laws, associations of water consumers are not profitable unions, however, this position had not been sufficiently stated in the laws that led to the occurrence of the conflicts of interests between the associations and financial structures $[3 ; 4]$.

The charge for the irrigation water supply was not sufficiently substantiated and very low that did not allow to form the budget of the associations. Agriculture continued to use old cultivation technologies of crops, and this did not allow to increase the yields on the irrigated lands. Water losses from the irrigation systems did not decrease either because of low coefficient of efficiency, no sufficient funding was collected for the reconstruction and modernization of the irrigation systems, and expenditures from the state budget for the maintenance and exploitation of the irrigation systems and water economy objects did not decrease [5]. Besides, associations of water consumers did not feel as valuable partners of the state bodies in the management of irrigation systems and water resources.

The efficiency of water resources and water economy management depends on the introduction of the principles of integrative water resource management. To introduce these principles considerable efforts should be done not only by the state and local management bodies but also by the organizations, which supply farms with irrigation water, and water consumers - farmers. In the annual budget of the country it is necessary to put considerable funding's for the realization of these principles but access to the funding's should have only those farmers, who unite into associations or cooperatives of water consumers by the territorial principle.

\section{References:}

1. Zakon Ukrainy (2010). "Pro derzhavno-pryvatne partnerstvo" [About state-private partnership]. Statements of the Verkhovna Rada of Ukrain (VVR), vol. 40, St. 524. (in Ukrainian)

2. Mishenina N.V., Yarova I.E., Mishenina H.A. (2017). Rozvytok mekhanizmiv derzhavnopryvatnoho partnerstva u sferi pryrodohospodariuvannia $\mathrm{v}$ umovakh detsentralizatsii [Development of state-private partnership mechanisms in the field of environmental management in conditions of decentralization]. Marketynh i menedzhment innovatsii, vol. 1, pp. 319-330. Retrieved from: http://mmi.fem.sumdu.edu.ua (in Ukrainian)

3. Otsenka deiatelnosty Assotsyatsyy vodopolzovatelei yuzhnukh oblastei Kurhuzskoi Respublyky (2017). [Estimation of the water-comsumers Association activity of the South areas of Kyrgyz Republic]. Retrieved from: http://www.osce.org/ru/bishkek/76143?download=tru (in Russian)

4. Syrozhydynov K. (2017). Assotsyatsyia vodopolzovatelei v Tadzhykystane: problem bolshe chem vozmozhnostei [An association of water-consumers in Tadjikistan: there are more problems than facilities]. Retrieved from: http://avesta.tj/2017/09/08/assotsiatsii-vodopolzovatelej-vtadzhikistane-problem-bolshe-chem-vozmozhnostej/ (in Russian)

5. Holian V.A. (2009). Derzhavno-pryvatne partnerstvo $v$ instytutsionalnii arkhitektonitsi vodokorystuvannia: svitovyi dosvid ta vitchyzniani realii [State-private partnership in institutional architectonics of water consumption: the world experience and national realities]. Ekonomika APK, vol. 5, pp. 8-15. (in Ukrainian) 